${ }^{8}$ Bernard, J, Jacquillat, C, and Weil, M, Seminars in Hematology, 1972, 9,181 .

${ }^{9}$ Brincker, H, Scandinavian fournal of Haematology, 1975, 14, 35

10 Spiers, A S D, et al, Cancer, In press.

11 Gale, R P, and Cline, M J, Lancet, 1977, 1, 497.

12 Crowther, D, et al, British Medical fournal, 1970, 2, 513.

13 Medical Research Council's Working Party on Leukaemia in Adults, British fournal of Haematology, 1974, 27, 373.

14 Wiernik, P H, and Serpick, A A, Medicine, 1970, 49, 505.

16 Beard, M E H, and Fairley, G H, Seminars in Hematology, 1974, 11, 5.

16 Crowther, D, et al, British Medical fournal, 1973, 1, 131.

12 Gutterman, J U, et al, Lancet, 1974, 2, 1405.

18 Spiers, A S D, Clinics in Haematology, 1972, 1, 127.

19 Frei, E, and Freireich, E J, Advances in Chemotherapy, 1965, 2, 269.

${ }^{20}$ Pinkel, D, fournal of the American Medical Association, 1971, 216, 648.

21 Pinkel, D, et al, Cancer, 1971, 27, 247.

2.2 Medical Research Council's Working Party on Leukaemia in Adults, British Medical fournal, 1963, 1, 7.
${ }^{23}$ Carey, R W, Cancer Research, 1970, 11, 15.

${ }^{24}$ Whitecar, J P, Bodey, G P, and Freireich, E J, Cancer Research, 1970, 11, 83.

${ }^{25}$ Murphy, M L, et al, Cancer Research, 1955, 2, 36.

${ }^{26}$ Boiron, M, et al, Lancet, 1969, 1, 330.

27 Goodell, B, Leventhal, B, and Henderson, E, Clinical Pharmacology and Therapeutics, 1971, 12, 599.

${ }^{28}$ Medical Research Council's Working Party on Leukaemia in Adults, British Medical fournal, 1966, 1, 1383.

${ }^{29}$ Acute Leukemia Group B, Cancer, 1975, 36, 1560.

${ }^{30}$ Clarkson, B D, et al, Cancer, 1975, 36, 775.

31 Spiers, A S D, et al, British Medical fournal, 1975, 4, 614.

${ }^{32}$ Fairley, G H, British fournal of Haematology, 1975, 31, suppl, p 181.

${ }^{33}$ Powles, R L, et al, British fournal of Cancer, 1977, 35, 265.

${ }_{34}$ Paolino, W, et al, British Medical fournal, 1973, 3, 567.

${ }^{35}$ Freireich, E J, et al, Archives of Internal Medicine, 1976, 136, 1417.

\title{
Contribution of atenolol, bendrofluazide, and hydrallazine to management of severe hypertension
}

\author{
R G WILCOX, J R A MITCHELL
}

British Medical fournal, 1977, 2, 547-550

\section{Summary}

The efficacy of various combinations of atenolol, bendrofluazide, and hydrallazine given twice daily was assessed in a double-blind trial on 29 patients with moderate to severe essential hypertension. Concurrent treatment with all three drugs proved most effective and produced a mean reduction in blood pressure of $43 / 31 \mathrm{~mm} \mathrm{Hg}$. In the dosage used, hydrallazine affected only the diastolic blood pressure, and when added to either bendrofluazide or bendrofluazide plus atenolol it produced a further mean reduction in pressure of $6 \mathrm{~mm} \mathrm{Hg}$. Once-daily treatment with atenolol and bendrofluazide was as effective in reducing blood pressure as the same combination given twice daily, and the hypotensive effect was still present at least 24 hours after the last dose of tablets. A combined tablet of atenolol and bendrofluazide taken once daily would be a simple regimen to follow and would provide almost as much hypotensive effect as a twice-daily regimen incorporating a modest dose of hydrallazine.

The hypotensive effect of atenolol was equal to that of bendrofluazide on systolic pressure but significantly better than that of bendrofluazide on diastolic pressure. Atenolol reduced plasma renin and urate concentrations but increased plasma potassium levels. The biochemical effects of atenolol, therefore, may be an advantage over those of bendrofluazide when deciding on first-line treatment for essential hypertension.

\section{Introduction}

Since hypertension is nearly always symptomless a complex treatment regimen that causes side effects is unlikely to be acceptable to patients. Because beta-blocking agents have a low

Department of Medicine, General Hospital, Nottingham NG1 6HA R G WILCOX, BSC, MRCP, lecturer in medicine

J R A MITCHELI, PHD, FRCP, professor of medicine

incidence of side effects they are widely used in hypertension. They may be combined with diuretics ${ }^{1}$ or with peripheral vasodilators ${ }^{2}$ to achieve an enhanced hypotensive effect, but this increases the number of tablets to be taken each day. Atenolol is a cardioselective beta-blocker, and it is effective when given once daily to patients with mild to moderate hypertension.' We set out to evaluate the relative contribution of each component of a beta-blocker-diuretic-peripheral vasodilator combination to the management of patients with more severe degrees of high blood pressure and to determine whether the most effective components of such a combination could be given once a day. The effect of the various hypotensive combinations on plasma renin and other biochemical indices was also investigated.

\section{Patients and methods}

Twenty-nine patients ( 22 men, 7 women) with non-malignant essential hypertension took part in the study. Informed consent was obtained in each case and the study was approved by the hospital's ethical committee. Most of the patients were already on hypotensive treatment and were referred because of difficulty with control or problems with unwanted drug effects.

Figure 1 shows the design of the trial. At the first referral visit any current treatment was stopped, and the patients were then seen every two weeks for the next eight weeks. After the first four weeks they were given placebo tablets resembling atenolol, bendrofluazide, and hydrallazine to take twice daily. The bendrofluazide placebo contained riboflavin, which is excreted in the urine and causes it to fluoresce under ultraviolet light, and this was used as a simple test of compliance during the next four weeks. During this run-in period the acetylator status of each patient was assessed with the use of Schroder's4

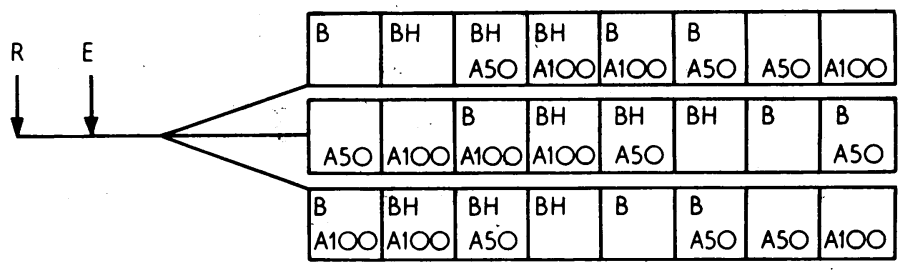

FIG. 1-Trial design. $R=$ First referral visit. $E=$ Entry to placebo period four weeks later. $\mathrm{B}=$ Bendrofluazide. $\mathrm{H}=$ Hydrallazine. $\mathrm{A} 50, \mathrm{~A} 100=$ Atenolol 50 and $100 \mathrm{mg}$. 
method, and if at the end of the period all urine tests showed fluorescence and the standing blood pressure exceeded $150 / 95 \mathrm{~mm} \mathrm{Hg}$ the patient continued in the study. The patients were allocated at random to various combinations of atenolol $50 \mathrm{mg}$ or $100 \mathrm{mg}$, bendrofluazide $2.5 \mathrm{mg}$, and hydrallazine $50 \mathrm{mg}$ given twice daily in one of three sequences (fig 1). Matching placebos were given, so that the patients always took three tablets twice daily irrespective of the number of active agents they were receiving. Each treatment period lasted four weeks, and on the last day of each period the patients were seen by an observer who did not know which treatment sequence had been used or which treatment block the patient was in.

At each visit the patient was weighed and the best of two peak expiratory flow rates recorded by means of a Wright peak flow meter. Blood pressure was measured by the same observer throughout with the use of a Hawksley random zero sphygmomanometer, diastolic blood pressure being taken at the point of disappearance of the Korotkoff sounds (phase 5). Supine blood pressure was measured after at least 10 minutes' rest, and standing blood pressure after being erect for one minute, the means of two readings in each position being recorded. Resting pulse rate was recorded and an indirect inquiry into unwanted symptoms made. After a further period of rest venous blood samples were taken for haematological and biochemical measurements, including renin. Each patient collected two 24-hour urine specimens during the run-in period and again towards the end of each four-week treatment period. We made no attempt to control dietary salt intake during the study.

Immediately on completing the double-blind study 11 patients continued treatment with once-daily atenolol $100 \mathrm{mg}$ plus bendrofluazide $5 \mathrm{mg}$ for a further four weeks, then atenolol $50 \mathrm{mg}$ plus bendrofluazide $5 \mathrm{mg}$ for another four weeks. Blood pressure was measured at the end of each four-week period, measurement being made at least $\mathbf{2 4}$ hours after the last dose of tablets. The effect of a one-minute vigorous stepping exercise on heart rate and standing blood pressure was also recorded at the end of the first four-week, once-daily treatment period. Twelve of the remaining patients were put back on to placebo tablets to assess the magnitude of any longterm placebo effect during the study.

Renin measurements-All the samples were collected at the same time of day (9-11 am) after 20-30 minutes' rest in the supine position. Samples were collected into $15 \mathrm{mM}$ EDTA and immediately centrifuged at $2000 \mathrm{rpm}$ at $4^{\circ} \mathrm{C}$ for 15 minutes. Plasma renin activity and concentration were measured according to the method of Skinner ${ }^{5}$ with radioimmunoassay of angiotensin I carried out by the method of Haber et al. ${ }^{6}$

Analysis-An analysis of variance for corrected means was used for the twice-daily study and Student's paired $t$ test for the once-daily study.

\section{Results}

Twenty-six patients completed the study, and their standing blood pressures at the end of the run-in placebo month ranged from $152 / 99$ to $247 / 155$ (mean $183 / 125$ ) $\mathrm{mm} \mathrm{Hg}$. One patient, a 52-year-old man, died suddenly from myocardial infarction during the third week of his sixth treatment period at a time when his blood pressure control had been good. Another man left the area, and a woman found the frequency of visits too demanding. All the treatment combinations produced a significant reduction in blood pressure (fig 2) compared with placebo $(P<0.001)$. There was no significant difference in hypotensive effect between atenolol $50 \mathrm{mg}$ or $100 \mathrm{mg}$ twice daily whether given alone or in combination with the other drugs. Atenolol alone produced a greater reduction in diastolic pressure than bendrofluazide (mean difference $5 \mathrm{~mm} \mathrm{Hg}$ ) but not in systolic pressure. The combination of atenolol and bendrofluazide was significantly better than either agent given alone $(P<0.001)$. The addition of hydrallazine to either bendrofluazide or bendrofluazide plus atenolol produced a further reduction in diastolic pressure by a mean of $6 \mathrm{~mm} \mathrm{Hg}(P<0.05)$ but there was no further reduction in systolic pressure. Bendrofluazide plus atenolol was significantly better than bendrofluazide plus hydrallazine only in respect of systolic blopd pressure $(P<0.001)$. The most effective combination overall was bendrofluazide plus atenolol and hydrallazine. On this triple regimen given twice daily a reduction in mean blood pressure of $43 / 31 \mathrm{~mm} \mathrm{Hg}$ was obtained in the standing position and $46 / 28 \mathrm{~mm} \mathrm{Hg}$ supine.

The trial design did not include washout periods between the different treatment blocks, but the drug combinations were given in three different sequences. The effect of each drug on blood pressure at the end of the four-week periods was not influenced by the sequence used, suggesting that any carryover effect was negligible.

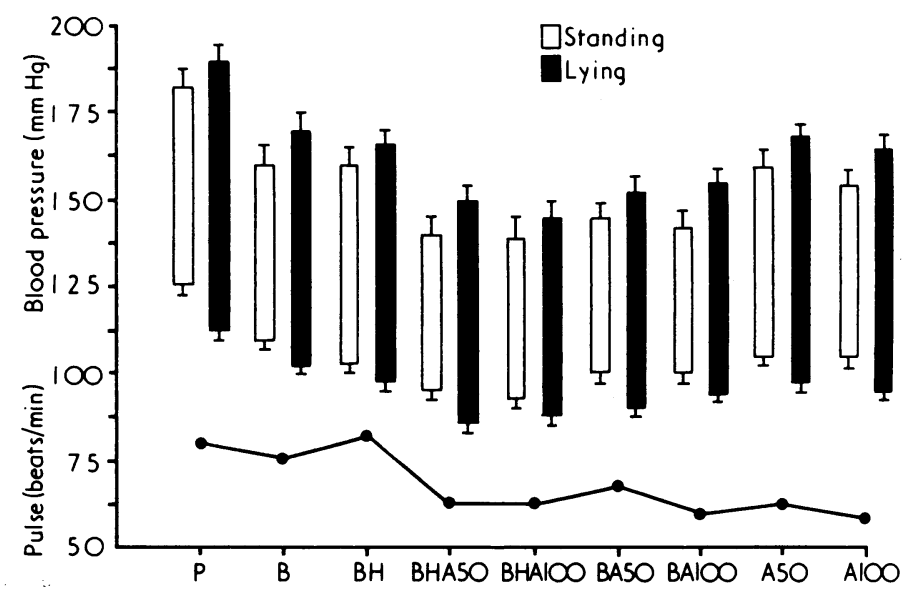

FIG $2-B l o o d$ pressure and hypotensive regimens. $P=P$ lacebo. $B=B$ endrofluazide. $\mathrm{H}=$ Hydrallazine. $\mathrm{A} 50, \mathrm{~A} 100=$ Atenolol 50 and $100 \mathrm{mg}$.

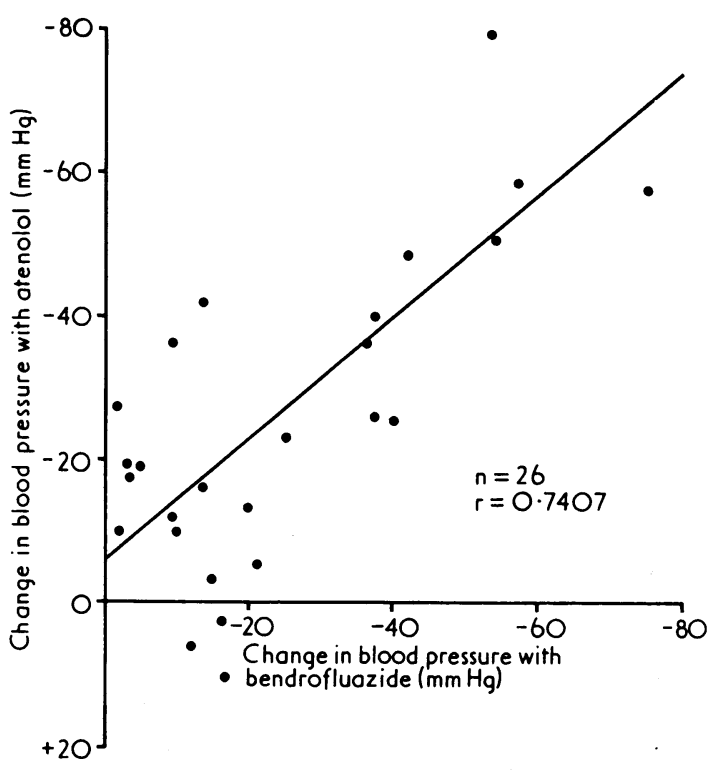

FIG 3-Comparison between change in blood pressure produced by atenolol $100 \mathrm{mg}$ twice daily and bendrofluazide $2.5 \mathrm{mg}$ twice daily.

The mean reduction in blood pressure produced by atenolol $(27 / 18 \mathrm{~mm} \mathrm{Hg})$ and bendrofluazide $(24 / 12 \mathrm{~mm} \mathrm{Hg})$ disguised the wide individual variation in response to these drugs (fig 3). The reason for this spectrum of effect is not known, for although there was a good correlation between initial blood pressure and the reduction brought about by either drug there was no correlation with any of the pretreatment biochemical measurements, including renin. We made no attempt to control sodium intake but collected 24-hour urine samples and found no correlation between sodium excretion and either the hypotensive response or the changes in renin activity and concentration.

Resting pulse rate was significantly reduced by all combinations containing atenolol $(P<0.001)$. Atenolol $100 \mathrm{mg}$ caused a slightly slower heart rate than atenolol $50 \mathrm{mg}$ by a mean of three beats/minute $(P<0.05)$. The addition of hydrallazine to either bendrofluazide or bendrofluazide plus atenolol produced a significant increase in heart rate by a mean of four beats/minute $(P<0.05)$.

There was no difference in response to any treatment regimen between patients who were slow acetylators $(n=17)$ and those who were fast acetylators $(n=9)$. On average, tests for antinuclear factor (ANF) gave positive results on two occasions in each treatment period. ANF was detected in four out of 52 tests in the fast acetylator group and 13 out of 119 tests in the slow acetylator group.

There were no significant changes in body weight or peak expiratory flow throughout the study.

In the 11 patients who entered the final phase of the study the effect of once-daily treatment with atenolol plus bendrofluazide was 
compared with the response they had shown on the twice-daily atenolol plus bendrofluazide regimen. There was no significant difference between the two regimens (fig 4), and the effect of oncedaily treatment on blood pressure was still present at least 24 hours after the last dose of tablets. Stepping exercise for one minute, however, caused a transient increase in pulse rate and systolic blood pressure at this time (fig 5).

In the 12 patients who were put back on to placebo tablets, blood pressures and pulse rates had returned to pretreatment levels by the end of week 4 (fig 6), suggesting that there had been no cumulative placebo effect and that complete washout of the drugs had occurred.

\section{BIOCHEMICAL CHANGES}

The effect of treatment on biochemical values is shown in the table. Plasma potassium was significantly increased by atenolol and reduced by bendrofluazide, although there was less of a reduction when bendrofluazide was given with atenolol. Plasma urate was significantly reduced by atenolol but was not significantly increased by bendrofluazide except, curiously, when combined with atenolol $100 \mathrm{mg}$.

Changes in renin concentration paralleled changes in renin activity throughout. Atenolol significantly reduced renin activity and bendrofluazide caused an increase. The addition of hydrallazine to bendrofluazide did not cause a further increase in renin activity, although there was a slight increase in renin concentration. The combination of atenolol plus bendrofluazide caused no significant changes in renin activity or concentration when compared with placebo. There was no correlation between the hypotensive effect of atenolol and either the initial renin status of the patient or the degree of reduction in renin activity or concentration. Furthermore, the hyporeninaemic effect of atenolol was the same whether the patient responded best to atenolol or to bendrofluazide.

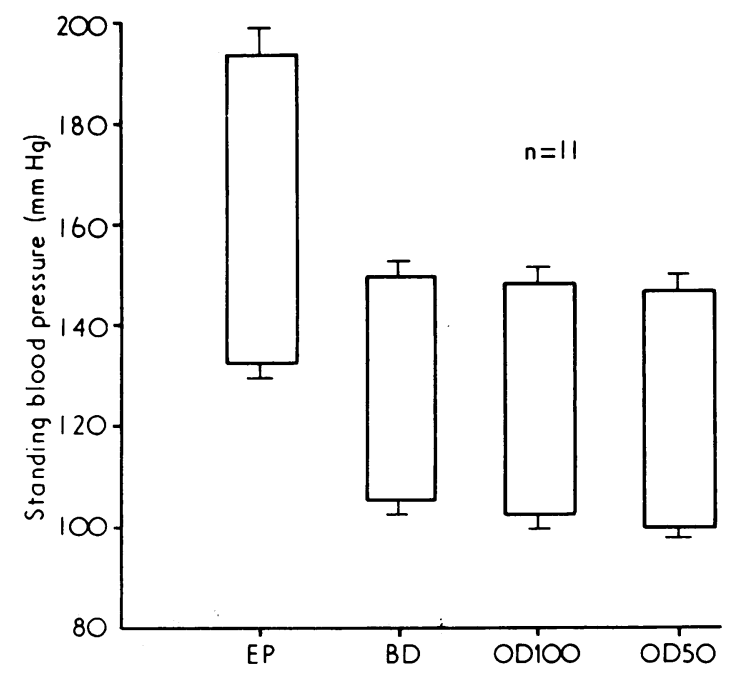

FIG 4-Once-daily $v$ twice-daily atenolol plus bendrofluazide. $\mathrm{EP}=$ End of placebo run-in period. $\mathrm{BD}=$ Atenolol plus bendrofluazide twice daily. OD100 $=$ Once-daily atenolol $100 \mathrm{mg}$ plus bendrofluazide $5 \mathrm{mg}$. OD $50=$ Once-daily atenolol $50 \mathrm{mg}$ plus bendrofluazide $5 \mathrm{mg}$. Blood pressures on once-daily regimens measured at least 24 hours after last dose of tablets.
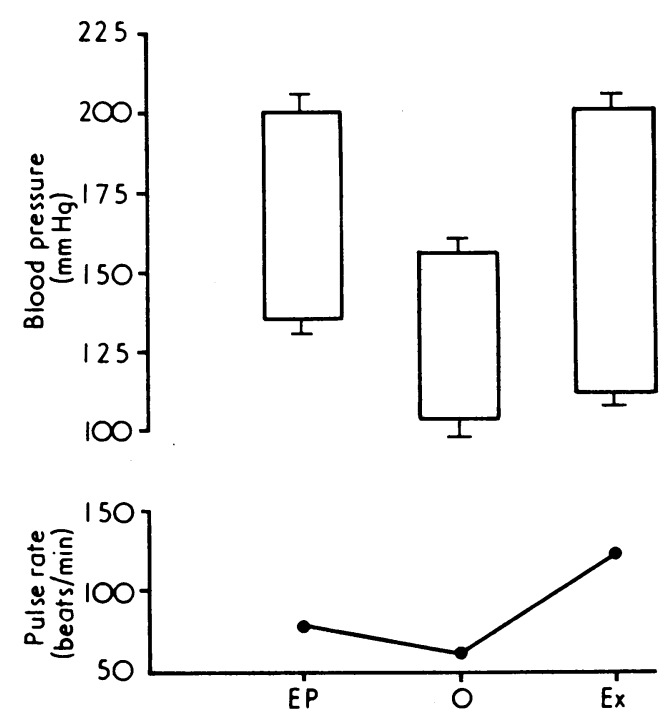

FIG 5-Effect of one-minute step exercise on pulse rate and standing blood pressure 24 hours after last dose of tablets. $E P=$ End of placebo run-in period (resting values). $\mathrm{O}=$ End of four weeks' treatment with atenolol $100 \mathrm{mg}$ plus bendrofluazide $5 \mathrm{mg}$ once daily (resting values). $\mathrm{Ex}=$ Effect of one-minute exercise.

\section{SIDE EFFECTS}

There were few side effects that could confidently be ascribed to any agent alone or to any particular combination. Thirteen patients admitted to having cold hands and feet at least once during the study, and this always coincided with a treatment regimen incorporating atenolol. There were two complaints of muscle fatigue during the study, and again these coincided with atenolol treatment. None of the symptoms caused the patients to stop taking any of the tablets.

\section{Discussion}

A combination of a beta-blocker, a diuretic, and a peripheral vasodilator should be complementary in reducing blood pressure. In our study such a combination, given twice daily, proved very effective in a group of patients with moderate to severe essential hypertension. The individual contribution made by hydrallazine in the dosage used was, however, small and was apparent only in respect of diastolic blood pressure, similar to the finding of Winchester et al. ${ }^{7}$ The combination of atenolol and bendrofluazide, therefore, was almost as good as the triple combination and was significantly better than either agent given alone. In 11 of the patients with severe essential hypertension (mean untreated blood pressure 195/130 mm Hg) oncedaily treatment with atenolol plus bendrofluazide was as effective as the same combination given twice daily. A single tablet that combined both these agents and could be taken once daily would be of considerable benefit to symptomless hypertensive patients.

Effect of treatment regimens on mean biochemical values $( \pm S E)$

\begin{tabular}{|c|c|c|c|c|c|c|c|c|c|}
\hline & \multirow{2}{*}{$\begin{array}{l}\text { End of } \\
\text { run-in }\end{array}$} & \multicolumn{7}{|c|}{ Treatments } & \multirow[b]{2}{*}{ A100 } \\
\hline & & B & BH & BHA50 & BHA100 & BA100 & BA50 & A50 & \\
\hline Plasma potassium $(\mathrm{mmol} / \mathrm{l})$ & $4.00 \pm 0.06$ & $3.61 \pm 0.08^{* * *}$ & $3.58 \pm 0.08^{* * *}$ & $3.81 \pm 0.08^{*}$ & $3.86 \pm 0.07$ & $3.82 \pm 0.07$ & $3.64 \pm 0.07^{* * *}$ & $4 \cdot 20 \pm 0.07^{* *}$ & $4 \cdot 26 \pm 0.08^{* *}$ \\
\hline $\begin{array}{l}\text { Plasma urate }(\mu \mathrm{mol} / \mathrm{l}) \\
\text { Plasma renin activity }(\mathrm{ng} / \mathrm{ml} / \mathrm{h})\end{array}$ & $\begin{array}{l}379 \pm 20 \\
1 \cdot 18 \pm 0 \cdot 15\end{array}$ & $\begin{array}{l}389 \pm 20(\mathrm{NS}) \\
1 \cdot 45 \pm 0 \cdot 21^{*}\end{array}$ & $\begin{array}{l}368 \pm 20(\mathrm{NS}) \\
1 \cdot 48 \pm 0 \cdot 20^{*}\end{array}$ & $\begin{array}{l}418 \pm 21(\mathrm{NS}) \\
1 \cdot 18 \pm 0 \cdot 20\end{array}$ & $\begin{array}{l}405 \pm 21(\mathrm{NS}) \\
1 \cdot 17 \pm 0 \cdot 21\end{array}$ & $\begin{array}{l}434 \pm 20^{*} \\
1 \cdot 05 \pm 0 \cdot 20\end{array}$ & $\begin{array}{l}396 \pm 27 \text { (NS) } \\
0.99 \pm 0 \cdot 15\end{array}$ & $\begin{array}{l}358 \pm 18^{* *} \\
0 \cdot 59 \pm 0 \cdot 07^{* *}\end{array}$ & $\begin{array}{l}359 \pm 18^{* *} \\
0.69 \pm 0.09 *\end{array}$ \\
\hline $\begin{array}{l}\text { Plasma renin concentration } \\
(\mathrm{ng} / \mathrm{ml} / \mathrm{h})\end{array}$ & $2 \cdot 48 \pm 0 \cdot 22$ & $3 \cdot 83 \pm 0.46^{*}$ & $4 \cdot 30 \pm 0 \cdot 70^{* *}$ & $\begin{array}{c}2 \cdot 87 \pm 0.42 \\
(\mathrm{NS})\end{array}$ & $\begin{array}{l}2 \cdot 62 \pm 0.39 \\
(\mathrm{NS})\end{array}$ & $\begin{array}{l}3 \cdot 10 \pm 0 \cdot 41 \\
(N S)\end{array}$ & $\begin{array}{l}3 \cdot 27 \pm 0.49 \\
(\mathrm{NS})\end{array}$ & $1 \cdot 70 \pm 0.38^{*}$ & $\underset{(\mathrm{NS})}{1.98 \pm 0.28}$ \\
\hline
\end{tabular}




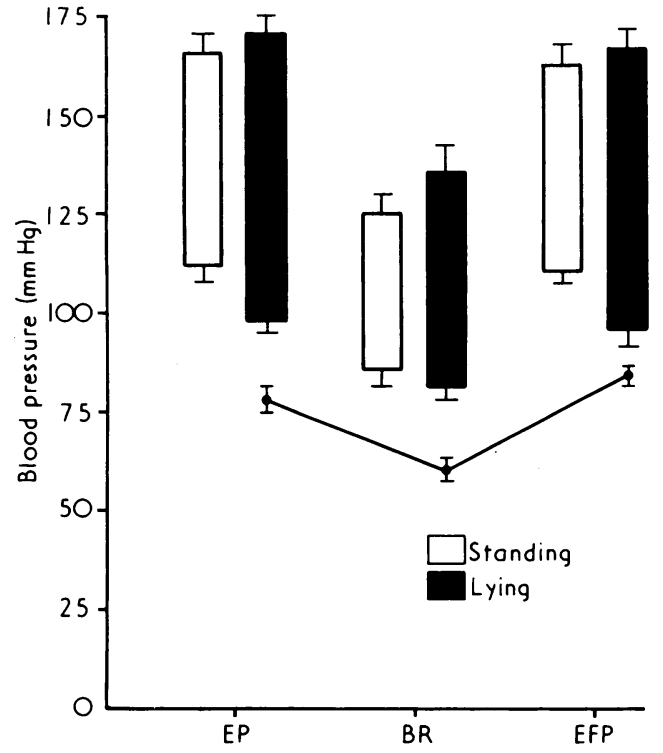

FIG 6-Effect of return to placebo tablets on pulse rate and blood pressure in 12 patients. $E P=$ End of placebo run-in period. $B R=$ Best response during active treatments. EFP $=$ End of final placebo period.

It has been suggested that patients with essential hypertension may fall into three groups ${ }^{8}$ : those with high renin levels, who respond best to beta-blockers; those with low renin levels, who respond best to diuretics; and those with normal renin, who respond equally to beta-blockers or diuretics. We could not identify any such subgroups in these few patients or any biochemical of physical marker that could have predicted a response to a diuretic or beta-blocker. Certainly atenolol had a greater hypotensive effect than bendrofluazide in some patients, but an equal number did better with bendrofluazide than with atenolol. This difference in response bore no relation to the hyporeninaemic effect of atenolol.

The decision to include patients with severe hypertension in a trial incorporating a placebo period was not taken lightly. Most of the patients in the trial were referred to us because they were not being controlled satisfactorily on existing regimens and it was not clear whether this was due to the regimens themselves or to lack of patient compliance. We regarded it as essential to establish the true level of untreated blood pressure and the degree of patient compliance by having a closely supervised placebo period and incorporating a riboflavin marker into one of the tablets. We found that the pressure levels recorded during our placebo period differed little from those achieved when the patients were on their previous "treatment" regimens.

The agent of first choice for treating hypertension is likely to depend on many factors. So far as atenolol and bendrofluazide are concerned there was no significant difference in their effect on systolic blood pressure, although atenolol was more effective than bendrofluazide on diastolic blood pressure $(P<0.05)$. The biochemical effects produced by the two agents may, however, be important in deciding which should be regarded as first-choice treatment. The acute and long-term effects of bendrofluazide (hypokalaemia, hyperuricaemia, and a tendency towards hyperglycaemia) are well known but are clinically not important. The long-term effects of atenolol are not yet known but it appears to have several, possibly advantageous biochemical effects - for example, reduction in plasma renin, a slight increase in serum potassium, and a small reduction in urate. It remains to be seen whether atenolol confers the same benefit in respect of myocardial infarction as has been shown with practolol ${ }^{9}$ and alprenolol. ${ }^{10}{ }^{11}$

Drugs and matching placebos were kindly supplied by the Boots Company Limited, Ciba, and ICI Limited. Renin measurements were made by Dr David Craven in the professorial department of obstetrics and gynaecology of the City Hospital, Nottingham.

\section{References}

1 Pritchard, B N C, and Gillam, P M S, British Medical fournal, 1969, 1, 7. 2 Zacest, R, Gilmore, E, and Koch-Weser, J, New England fournal of Medicine, 1972, 286, 617.

3 Douglas-Jones, A P, and Cruickshank, J M, British Medical fournal, 1976, 1, 990.

4 Schroder, H, British Medical fournal, 1972, 3, 506.

5 Skinner, S L, Circulation Research, 1967, 20, 391.

${ }^{6}$ Haber, E, et al, fournal of Clinical Endocrinology, 1969, 29, 1349.

7 Winchester, J F, et al, British fournal of Clinical Pharmacology, 1976, 3 863.

${ }^{8}$ Laragh, J H, et al, American fournal of Medicine, 1972, 52, 633.

${ }^{9}$ Multicentre International Study, British Medical fournal, 1975, 3, 735

10 Wilhelmsson, C, et al, Lancet, 1974, 2, 1157.

11 Ahlmark, G, Saetre, H, and Korsgrain, M, Lancet, 1974, 2, 1563.
Cardiac Department, Victoria Infirmary, Glasgow G42 9TY

R H BAXTER, MB, MRCP, senior registrar

I M LENNOX, MB, MRCP, registrar associated with changes in heart rate and blood pressure suggestive of a fall in left ventricular work.

The effect of isosorbide lasts for at least two hours and when taken before exercise may be a useful addition to beta-blockade in patients with angina.

\section{Introduction}

Beta-blockers are now established in the medical management of angina pectoris. Their beneficial effects, which include increased exercise tolerance and decreased frequency of anginal attacks, ${ }^{1-3}$ are continuous throughout the day. The clinical response to beta-blockade may be partial as some patients still have limiting angina. Furthermore, these drugs diminish con- 